\title{
Protocol Deviation Start Time
}

National Cancer Institute

\section{Source}

National Cancer Institute. Protocol Deviation Start Time. NCI Thesaurus. Code C83132.

The time at which the protocol deviation begins. 